\title{
Optimized and validated flow-injection spectrophotometric analysis of topiramate, piracetam and levetiracetam in pharmaceutical formulations
}

\author{
GHADA M. HADAD 1 \\ RANDA A. ABDEL-SALAM ${ }^{1}$ \\ SAMY EMARA ${ }^{2}$ \\ 1 Pharmaceutical Analytical Chemistry \\ Department, Faculty of Pharmacy \\ University of Suez Canal \\ Ismailia 41522, Egypt \\ 2 Pharmaceutical Analytical Chemistry \\ Department, Faculty of Pharmacy \\ Misr International University, Egypt
}

\begin{abstract}
Application of a sensitive and rapid flow injection analysis (FIA) method for determination of topiramate, piracetam, and levetiracetam in pharmaceutical formulations has been investigated. The method is based on the reaction with ortho-phtalaldehyde and 2-mercaptoethanol in a basic buffer and measurement of absorbance at $295 \mathrm{~nm}$ under flow conditions. Variables affecting the determination such as sample injection volume, $\mathrm{pH}$, ionic strength, reagent concentrations, flow rate of reagent and other FIA parameters were optimized to produce the most sensitive and reproducible results using a quarter-fraction factorial design, for five factors at two levels. Also, the method has been optimized and fully validated in terms of linearity and range, limit of detection and quantitation, precision, selectivity and accuracy. The method was successfully applied to the analysis of pharmaceutical preparations.
\end{abstract}

Keywords: topiramate, piracetam, levetiracetam, flow-injection analysis

Flow injection analysis (FIA) has become a technique of increasing importance in pharmaceutical analysis because of its implicit simplicity, low cost and rapid approach. FIA is a continuous flow method in which a small plug of sample is injected into a flowing reagent stream. Mixing occurs by diffusion and the reaction product is monitored downstream to give a transient peak signal.

Topiramate (TP), a sulfamate-substituted monosaccharide, is an antiepileptic used as adjunctive therapy in adults and children over 2 years for refractory partial seizures with or without secondary generalization (1). Piracetam (PC) acts on the CNS; it has been described as a 'nootropic' and is said to protect the cerebral cortex against hypoxia (1). Levetiracetam (LV) is an analogue of piracetam used as adjunctive therapy in the treatment of partial seizures with or without secondary generalization (1).

* Correspondence; e-mail: ghhadad@hotmail.com 
G. M. Hadad et al.: Optimized and validated flow-injection spectrophotometric analysis of topiramate, piracetam and levetiracetam in pharmaceutical formulations, Acta Pharm. 61 (2011) 377-389.

HPLC was used for determination of TP and its impurities (2), TP and its degradation product (3) and for determination of TP in human serum (4). Furthermore, HPLC was used for determination of PC and its impurities (5). PC in pharmaceutical dosage form was determined using HPLC (6) and derivative spectrophotometry (7). PC in combination with vincamine or cinnarizine was determined using HPLC and spectrophotometry $(8,9)$. HPLC was used for determination of LV stability (10), LV enantiomers (11) and LV in tablets (12).

PC and LV had relatively low ultra violet absorbance while TP had no significant absorbance. Thus, using direct UV absorption in determination of such drugs may be subject to interference from soluble excipient particles commonly found in pharmaceutical formulations. The goal of this work was to develop a FIA spectrophotometric procedure for the determination of TP, PC, and LV based on formation of derivatives using ortho-phtalaldehyde (OPA) and 2-mercaptoethanol (ME). Derivatization of these drugs with OPA in the presence of ME (which contains a thiol group) at alkaline $\mathrm{pH}$, and coupled with FIA, gives an ideal analytical method for routine analysis and quality assurance, since derivatization increases the sensitivity.

\section{EXPERIMENTAL}

\section{Reagents and chemicals}

Pharmaceutical grade TP (Sigma-Aldrich, USA), PC (Sigma-Aldrich) and LV (Sigma-Aldrich) were used and certified to contain 99.7, 99.7 and 99.9 of drug, respectively. Methanol HPLC grade (Sigma-Aldrich) was used. OPA, ME, boric acid and sodium hydroxide were of analytical grade (Sigma-Aldrich).

Pharmaceutical formulations of TP (Topiramate ${ }^{\circledR}$ tablets, $25 \mathrm{mg}$ TP) were manufactured by Kahira Pharm. and Chemical Industries Co. (Egypt). Delpiramate ${ }^{\circledR}$ tablets (100 mg TP) were manufactured by Delta Pharma S.A.E. (Egypt). Pharmaceutical formulations of PC, Stimulan ${ }^{\circledR}$ capsules (400 mg PC and tablets 800 mg PC) were manufactured by Amoun Pharmaceutical Co. (Egypt). Nootropil ${ }^{\circledR}$ capsules (400 mg PC) and tablets $(800 \mathrm{mg}$ PC) were manufactured by Chemical Industries Development Co. (Egypt). Pharmaceutical formulations of LV, Tiratam ${ }^{\circledR}$ tablets $(500 \mathrm{mg} \mathrm{LV})$ were manufactured by the Al-Andalous medical company (Egypt). All dosage forms used were purchased from local commercial sources.

Alkaline borate buffer solutions ( 0.1 or $0.4 \mathrm{~mol} \mathrm{~L}^{-1}$ ionic strength) were made by dissolving boric acid in water and were adjusted to the desired $\mathrm{pH}$ (9.4 or 11.4) with $\mathrm{NaOH}$.

Stock solution of OPA ( $1 \%$ in $\mathrm{MeOH})$ was prepared. The carrier (reagent) stream consisted of OPA and ME dissolved in borate buffer solutions. Buffer $\mathrm{pH}$ and ionic strength, $\mathrm{ME}$ volume and OPA concentration varied according to the experimental design.

\section{Apparatus}

A single line FIA manifold was employed with a reaction coil of $0.75 \mathrm{~m}$ length. Samples were loaded into a 20- $\mu \mathrm{L}$ sample loop (Rheodyne 7725i) (Shimadzu, Japan) manual 
G. M. Hadad et al.: Optimized and validated flow-injection spectrophotometric analysis of topiramate, piracetam and levetiracetam in pharmaceutical formulations, Acta Pharm. 61 (2011) 377-389.

injection valve to inject working and sample solutions into the carrier stream. The latter was sonicated to release possible air bubbles. A model LC-10 ADVP pump (Shimadzu) was used to deliver the carrier reagent at a flow rate of $0.5 \mathrm{~mL} \mathrm{~min}^{-1}$. A model Lambda SPD-10AVP UV-VIS detector (Shimadzu) was used for the detection of derivatized products of TP, PC and LV. Data acquisition was performed on class-VP software.

\section{Sample preparation}

Ten tablets for TP or LV and ten capsules or tablets for PC were weighed and finely powdered. A portion of the powder equivalent to about $50 \mathrm{mg}$ of TP, PC or LV was accurately weighed, dissolved and diluted to $100 \mathrm{~mL}$ with methanol. The sample solution was filtered. Further dilutions of the sample solution were suitably carried out with methanol to reach the linearity range. This diluted sample solution was injected into the FIA manifold and the peak height was interpolated into the calibration graph.

\section{Optimization of the flow injection assay}

The factors investigated during the optimization were the concentration of OPA (A) and volume of $\mathrm{ME}(\mathrm{B})$ in the reagent, $\mathrm{pH}(\mathrm{C})$ and ionic strength (D) of the buffer, and the reagent flow rate $(\mathrm{E})$. Selection of upper and lower limits of these factors was done using a screening design. These levels were based on literature data (13), on stoichiometric calculations for the chemical reaction parameters and on the experiments, so that the residence time (the time from injection to the peak maximum) levels would be between 15 and $25 \mathrm{~s}$ for complete reaction.

Table I. Factors and levels for quarter-fraction factorial design $2_{I I I}^{5-2}$

\begin{tabular}{crrrrr}
\hline & \multicolumn{5}{c}{ Factor $^{\mathrm{a}}$} \\
\cline { 2 - 6 } Experiment & $\begin{array}{c}\text { OPA conc. (mg per } \\
100 \mathrm{~mL} \text { borate buffer })\end{array}$ & $\mathrm{ME}(\mu \mathrm{L})$ & Reagent $\mathrm{pH}$ & $\begin{array}{c}\text { Ionic strength } \\
\left(\mathrm{mol} \mathrm{L}^{-1}\right)\end{array}$ & $\begin{array}{c}\text { Flow rate } \\
\left(\mathrm{mL} \mathrm{min}^{-1}\right)\end{array}$ \\
\cline { 2 - 6 } & $\mathrm{A}$ & $\mathrm{B}$ & $\mathrm{C}$ & $\mathrm{D}$ & $\mathrm{E}$ \\
\hline 1 & -1 & -1 & -1 & 1 & 1 \\
2 & 1 & -1 & -1 & -1 & -1 \\
3 & -1 & 1 & -1 & -1 & 1 \\
4 & 1 & 1 & -1 & 1 & -1 \\
5 & -1 & -1 & 1 & -1 & -1 \\
7 & 1 & -1 & 1 & -1 & -1 \\
\hline
\end{tabular}

a Lower $(-1)$ and upper levels (+1): of OPA concentration are 50 and $100 \mathrm{mg}$ per $100 \mathrm{~mL}$ borate buffer; of ME 50 and $100 \mu \mathrm{L}$; of reagent $\mathrm{pH} 9.4$ and 11.4; of reagent ionic strength 0.1 and $0.4 \mathrm{~mol} \mathrm{~L}^{-1}$; of reagent flow rate 0.5 and $1 \mathrm{~mL} \mathrm{~min}^{-1}$. 
G. M. Hadad et al.: Optimized and validated flow-injection spectrophotometric analysis of topiramate, piracetam and levetiracetam in pharmaceutical formulations, Acta Pharm. 61 (2011) 377-389.

A quarter-fraction factorial design for five factors at two levels was used to screen the effects of the factors on peak height. For each factor, an upper $(+1)$ and a lower $(-1)$ level were defined (Table I). Only $2^{5-2}$ (eight) experiments have to be performed (Table I).

The effect of each variable on the response is calculated as the difference between the average results at the $(+1)$ level and at the $(-1)$ level of the variable:

$$
E_{\mathrm{x}}=\frac{\Sigma Y(+1)}{n}-\frac{\Sigma Y(-1)}{n}
$$

where $\Sigma Y(+1)$ and $\Sigma Y(-1)$ are the sums of the responses where factor $x$ is at its high $(+1)$ and at its low (-1) level, respectively, and $n$ is the number of times each factor is at the $(+1)$ or $(-1)$ level. Normalized effects $\left(\% E_{\mathrm{x}}\right)$ can be calculated as $\% E_{\mathrm{x}}=\left(E_{\mathrm{x}} / Y^{\prime}\right)^{*} 100$ with $Y \backslash$ being the average nominal peak height (Table II).

\section{Validation}

Fifty $\mathrm{mg}$ of TP, PC and LV were separately dissolved in $100 \mathrm{~mL}$ methanol. Diluted standard solutions were prepared by appropriate dilutions with methanol to reach a concentration range of $5-35 \mu \mathrm{g} \mathrm{mL}-1$ of each drug. This solution was injected into a FIA manifold and the peak height was plotted against the corresponding concentration to obtain the calibration graph.

Linearity and range. - Linearity of the proposed method was evaluated by analyzing seven concentrations of each drug within the concentration range mentioned above. Each concentration was measured three times. The assay was performed according to experimental conditions previously established. The calibration graph was constructed by plotting the peak height measured at $295 \mathrm{~nm}$ against the corresponding concentrations of TP, PC, or LV.

Selectivity. - A synthetic mixture consisting of the drug (TP, PC or LV), talc, starch, lactose, magnesium stearate, microcrystalline cellulose in the ratio 1:1.5:2:1.5:3:2.5 was prepared by thorough mixing of the constituents. An amount of the mixture equivalent to $50 \mathrm{mg}$ of each drug was accurately weighed, dissolved and diluted to $100 \mathrm{~mL}$ with methanol. The solution was filtered. Further dilutions were suitably carried out with

Table II. Effects of the factors on the peak height calculated from the quarter-fraction factorial design $2^{5-2}$

\begin{tabular}{lrrr}
\hline \multirow{2}{*}{ Factor } & \multicolumn{3}{c}{ Effect $(\%)$} \\
\cline { 2 - 4 } & $\mathrm{TP}$ & \multicolumn{1}{c}{ PC } & \multicolumn{1}{c}{ LT } \\
\hline OPA conc. & -0.87 & -0.27 & -7.24 \\
ME volume & 0.68 & 5.91 & 5.79 \\
Reagent pH & -0.25 & -1.47 & -6.27 \\
Buffer ionic strength & -0.37 & -16.21 & -1.35 \\
Flow rate & 0.50 & 0.69 & 1.62 \\
\hline
\end{tabular}


G. M. Hadad et al.: Optimized and validated flow-injection spectrophotometric analysis of topiramate, piracetam and levetiracetam in pharmaceutical formulations, Acta Pharm. 61 (2011) 377-389.

methanol to reach the linearity range. The steps described under the assay of dosage forms were followed to determine the percent recovery of each drug.

Precision. - For 5.0, 10.0 and $35.0 \mu \mathrm{g} \mathrm{mL}^{-1}$ of each drug, the assay described under the general analytical procedure was repeated three times within a day to determine the repeatability (intra-day precision) and eight times on different days to determine the intermediate precision (inter-day precision) of the method. Relative standard deviation values for TP, PC and LV for intra-day precision and inter-day precision were calculated.

Detection and quantitation limits. - The limit of detection $(L O D)$ and limit of quantification $(L O Q)$ were calculated according to the current ICH guidelines as the ratio of 3.3 and 10 standard deviations of the blank $(n=7)$, respectively, and the slope of the calibration line (14).

Accuracy. - The validity of the proposed method for determination of the drug in pharmaceutical formulations was tested by applying the standard addition technique. The study was performed by addition of known amounts of the studied compound to the known concentration of a commercial pharmaceutical product.

\section{RESULTS AND DISCUSSION}

Direct spectrophotometric determination of TP, PC and LV has poor sensitivity due to low UV absorption of the compounds tested (Fig. 1a). TP, PC, and LV contain a primary aliphatic amino group, which is known to react with OPA in the presence of ME (which contains a thiol group) at alkaline $\mathrm{pH}$ (Scheme 1) (15). A reagent consisting of OPA and ME in an alkaline borate buffer is pumped through the FIA manifold. Each drug solution is injected into the flowing stream. TP, PC, and LV react with the reagent stream yielding a derivative which can be measured spectrophotometrically at $295 \mathrm{~nm}$ (Fig. 1b). Preliminary experiments were done to achieve two objectives. The first was to determine the optimal detection wavelength and the second to examine the most effective way for signal processing (peak height versus peak area).

Signal processing using peak height proved to be advantageous over peak area in term of accuracy. Under the specified experimental conditions, the recovery \pm SD for TP, PC and LV was $97.6 \pm 0.4,98.1 \pm 0.3$ and $99.0 \pm 0.3 \%$, respectively, for peak height

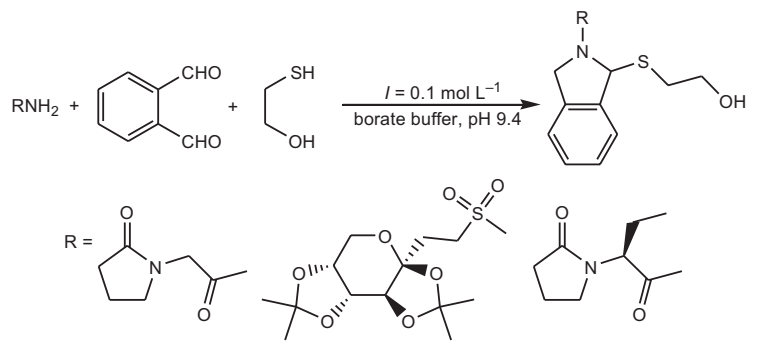

Scheme 1. 
G. M. Hadad et al.: Optimized and validated flow-injection spectrophotometric analysis of topiramate, piracetam and levetiracetam in pharmaceutical formulations, Acta Pharm. 61 (2011) 377-389.

and $103.2 \pm 3.5,103.5 \pm 3.5$ and $99.7 \pm 3.4 \%$, respectively, for peak area evaluation (for $n=7$ in both cases). Peak height was selected as the preferred approach for signal evaluation.

\section{Optimization of the flow injection assay}

The values of the effects of variables, which are presented in Table II, indicate that the concentration of OPA, ionic strength, and $\mathrm{pH}$ of the solution have a negative significant effect on the peak height while the volume of $\mathrm{ME}$ and flow rate have a positive significant effect. This means that the low level of OPA concentration (50 mg per $100 \mathrm{~mL}$ ) gave a higher peak than the high level (100 mg per $100 \mathrm{~mL})$. Experiments, done at OPA concentration of 10 and $40 \mathrm{mg}$ per $100 \mathrm{~mL}$ gave poorer responses than the concentration of $50 \mathrm{mg}$ per $100 \mathrm{~mL}$ (concentration defined as optimal).

The maximum analytical response was obtained at ionic strength of $0.1 \mathrm{~mol} \mathrm{~L}^{-1}$ and this value was defined as the optimal one. The responses deteriorated at ligher $\left(0.4 \mathrm{~mol} \mathrm{~L}^{-1}\right)$ and lower $\left(0.05\right.$ and $\left.0.07 \mathrm{~mol} \mathrm{~L}^{-1}\right)$ ionic strength.

Reagent $\mathrm{pH}$ of 9.4 gave a higher peak than $\mathrm{pH}$ 11.4. At $\mathrm{pH} 8$ the results deteriorated and the optimal reagent $\mathrm{pH}$ was defined as 9.4.
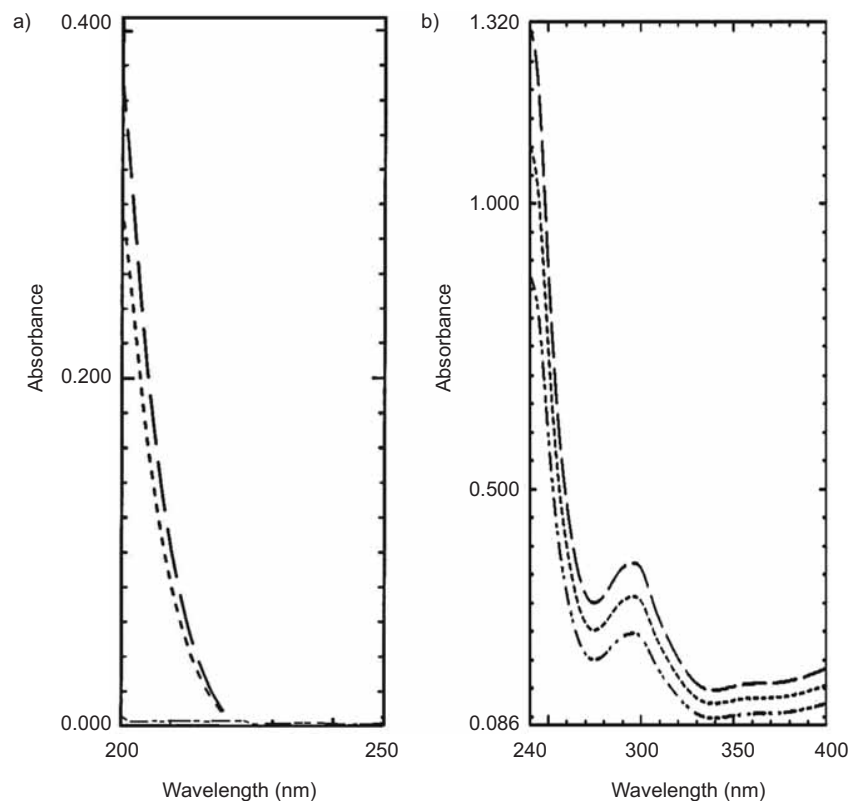

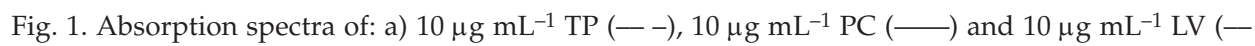
-) and b) reaction product of $10 \mu \mathrm{g} \mathrm{mL}^{-1} \mathrm{TP}(--), 10 \mu \mathrm{gL}^{-1} \mathrm{PC}(---)$ and $10 \mu \mathrm{g} \mathrm{mL}^{-1} \mathrm{LV}(--)$ with OPA and ME in a borate buffer ( $\mathrm{pH} 9.4), I=0.1 \mathrm{~mol} \mathrm{~L}^{-1}$, against reagent blank. 
The higher level of ME volume $(100 \mu \mathrm{L})$ gave a higher peak than the lower level $(50 \mu \mathrm{L})$. By the use of $150 \mu \mathrm{L}$ ME no significant increase in response was observed.

Also, at higher level of flow rate $\left(1 \mathrm{~mL} \mathrm{~min}^{-1}\right)$ a higher peak was obtained than at the lower level $\left(0.5 \mathrm{~mL} \mathrm{~min}^{-1}\right)$. Since flow rate of $1 \mathrm{~mL} \mathrm{~min}^{-1}$ gave a residence time of approximately $10 \mathrm{~s}$ and this time was too short for reaction to complete, in further optimization the flow rate was set at $0.5 \mathrm{~mL} \mathrm{~min}^{-1}$, which assured residence time of approximately $20 \mathrm{~s}$.

The effect of the volume of injected sample was studied in the range of 10-50 $\mu \mathrm{L}$. A non-linear increase of the signal was observed within that range. This was expected, since the volume of the sample injected in a FIA system is inversely proportional to the dispersion of the sample zone. The value of $20 \mu \mathrm{L}$ was selected for further experiments as a compromise between sensitivity and linear concentration range.

The length of the tubing was first varied between the limits of 0.5 and $2 \mathrm{~m}$. These experiments have shown that the shorter the length of the tubing, the higher the peak obtained for TP, PC and LV. This result is what one expects for fast chemical reactions, because the shorter the length, the smaller will be the dispersion of the sample zone. Since the repeatability for a tubing length of $0.5 \mathrm{~m}$ was not good, a tubing length of $0.75 \mathrm{~m}$ was chosen for in further experiments.

Typical FIA recordings for TP, PC and LV are given in Fig. 2.
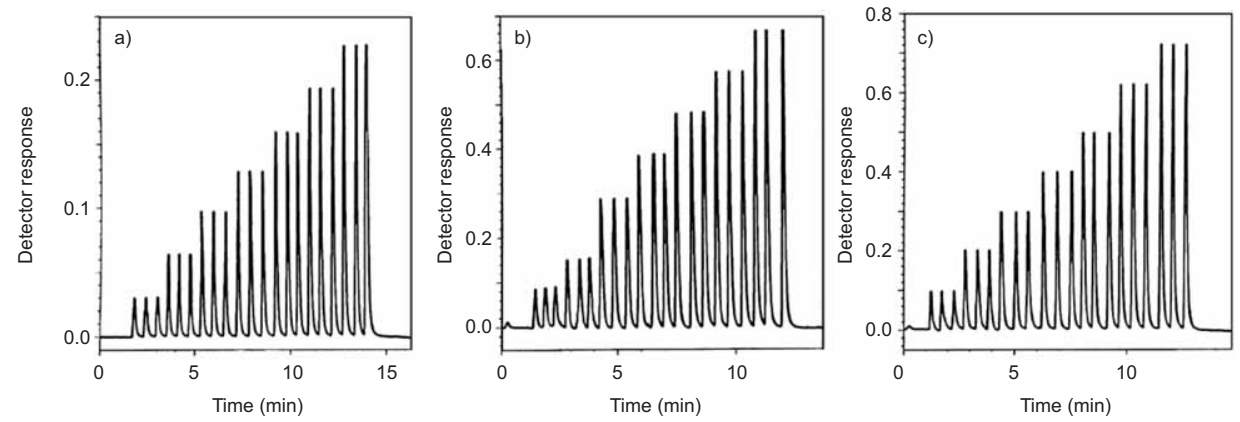

Fig. 2. Typical FIA results $(n=3)$ for the calibration graph of: a) TP, b) PC and c) LV.

\section{Validation}

Calibration plots for TP, PC and LV assays were linear over the calibration range 5-35 $\mu \mathrm{g} \mathrm{mL}^{-1}$ (Table III).

Relative standard deviation values for TP, PC and LV were found to be 1.3, 1.2 and $1.0 \%$ for repeatability (intra-day precision) and 2.0, 1.7 and $1.5 \%$ for intermediate precision (inter-day precision), respectively, indicating high precision of the method. 
G. M. Hadad et al:: Optimized and validated flow-injection spectrophotometric analysis of topiramate, piracetam and levetiracetam in pharmaceutical formulations, Acta Pharm. 61 (2011) 377-389.

Table III. Characteristic parameters of calibration equations for the proposed spectrophotometric method for determination of TP, $P C$ and $L V$

\begin{tabular}{lccc}
\hline Parameter & TP & PC & LV \\
\hline $\begin{array}{l}\text { Calibration range } \\
\left.(\mu \mathrm{g} \mathrm{mL})^{-1}\right)\end{array}$ & $5-35$ & $5-35$ & $5-35$ \\
$\begin{array}{l}\text { Detection limit } \\
\left.(\mu \mathrm{g} \mathrm{mL})^{-1}\right)\end{array}$ & 0.02 & 0.04 & 0.04 \\
$\begin{array}{l}\text { Quantitation limit } \\
\left.(\mu \mathrm{g} \mathrm{mL})^{-1}\right)\end{array}$ & 0.07 & 0.11 & 0.13 \\
$\begin{array}{l}\text { Regression equa- } \\
\text { tion }(Y)^{\mathrm{a}} \text { : }\end{array}$ & $1.52 \times 10^{3} \pm 13.50$ & $1.93 \times 10^{3} \pm 27.91$ & $2.30 \times 10^{3} \pm 38.89$ \\
$\begin{array}{l}\text { Slope }(b) \pm \mathrm{SD} \\
\begin{array}{l}\text { Confidence interval } \\
\text { of the slope }\end{array}\end{array}$ & $(1.50-1.53) \times 10^{3}$ & $(1.91-1.96) \times 10^{3}$ & $(2.26-2.34) \times 10^{3}$ \\
$\begin{array}{l}\text { Intercept }(a) \pm \mathrm{SD} \\
\text { Confidence interval } \\
\text { of the intercept }\end{array}$ & $-1.10 \times 10^{2} \pm 3.02 \times 10^{2}$ & $-3.95 \times 10^{2} \pm 6.24 \times 10^{2}$ & $5.43 \times 10^{2} \pm 8.69 \times 10^{2}$ \\
$\begin{array}{l}\text { Correlation } \\
\text { coefficient }(R)\end{array}$ & $\left.0.999 \times 10^{2}\right)-\left(1.83 \times 10^{2}\right)$ & $\left(-10.02 \times 10^{2}\right)-\left(2.12 \times 10^{2}\right)$ & $\left(-3.01 \times 10^{2}\right)-\left(13.88 \times 10^{2}\right)$ \\
\hline
\end{tabular}

a $Y=a+b \gamma$, where $\gamma$ is the concentration of TP, PC and LV in $\mu \mathrm{g} \mathrm{mL}^{-1}$ and $Y$ is peak height.

b $95 \%$ confidence limit.

Table IV. Selectivity data

\begin{tabular}{|c|c|c|c|c|c|c|c|}
\hline \multirow{2}{*}{$\begin{array}{l}\text { Drug } \\
\text { analyte }\end{array}$} & \multicolumn{6}{|c|}{ Composition of the synthetic mixture (mg) } & \multirow{2}{*}{$\begin{array}{c}\text { Drug } \\
\text { recovered }(\%)^{\mathrm{a}}\end{array}$} \\
\hline & Drug & Talc & Starch & Lactose & $\begin{array}{l}\text { Magnesium } \\
\text { stearate }\end{array}$ & $\begin{array}{l}\text { Microcrystalline } \\
\text { cellulose }\end{array}$ & \\
\hline TP & 200 & 300 & 400 & 300 & 600 & 500 & $99.6 \pm 0.6$ \\
\hline PC & 200 & 300 & 400 & 300 & 600 & 500 & $99.4 \pm 0.8$ \\
\hline LV & 200 & 300 & 400 & 300 & 600 & 500 & $100.3 \pm 0.6$ \\
\hline
\end{tabular}

a Mean \pm SD, $n=5$.

Detection limits for TP, PC and LV were estimated as $0.02,0.04$ and $0.04 \mu \mathrm{g} \mathrm{mL}^{-1}$, respectively, and the quantitation limits for TP, PC and LV were $0.07,0.11$ and $0.13 \mu \mathrm{g} \mathrm{mL}^{-1}$, respectively.

The results of selectivity studies, as shown in Table IV, confirm that the proposed method is selective, accurate and precise even in the presence of various excipients.

The percentage recovery values obtained for TP, PC and LV were in the range from 99.3-101.3, 98.3-100.4 and 99.7-100.2\%, respectively. In all cases, the results showed fairly good accuracy of the method (Table V). 
G. M. Hadad et al.: Optimized and validated flow-injection spectrophotometric analysis of topiramate, piracetam and levetiracetam in pharmaceutical formulations, Acta Pharm. 61 (2011) 377-389.

Table V. Recovery study by the standard addition method

\begin{tabular}{|c|c|c|c|c|}
\hline Drug & $\begin{array}{l}\text { Pharmaceutical prepa- } \\
\text { ration brand name }\end{array}$ & $\begin{array}{l}\text { Drug in pharmaceutical pre- } \\
\text { paration extract }\left(\mu \mathrm{g} \mathrm{mL} \mathrm{m}^{-1}\right)\end{array}$ & $\begin{array}{l}\text { Pure drug added } \\
\qquad(\mu \mathrm{g} \mathrm{mL}-1)\end{array}$ & $\begin{array}{l}\text { Drug recovered } \\
\qquad(\%)^{\mathrm{a}}\end{array}$ \\
\hline \multirow{6}{*}{$\mathrm{TP}$} & \multirow{3}{*}{ Topiramate tablets ${ }^{\circledR}$} & 10.00 & 6.00 & $99.8 \pm 0.8$ \\
\hline & & 10.00 & 8.00 & $99.7 \pm 0.8$ \\
\hline & & 10.00 & 10.00 & $101.3 \pm 0.8$ \\
\hline & \multirow{3}{*}{ Delpiramate Tablets ${ }^{\circledR}$} & 10.00 & 6.00 & $99.7 \pm 0.9$ \\
\hline & & 10.00 & 8.00 & $99.3 \pm 0.8$ \\
\hline & & 10.00 & 10.00 & $100.7 \pm 0.8$ \\
\hline \multirow{6}{*}{\multicolumn{2}{|c|}{ Stimulan capsules ${ }^{\circledR}$}} & 15.00 & 12.00 & $99.6 \pm 0.8$ \\
\hline & & 15.00 & 14.00 & $100.3 \pm 0.8$ \\
\hline & & 15.00 & 20.00 & $99.4 \pm 0.8$ \\
\hline & & 15.00 & 12.00 & $99.7 \pm 0.7$ \\
\hline & & 15.00 & 14.00 & $98.6 \pm 0.6$ \\
\hline & & 15.00 & 20.00 & $99.6 \pm 0.6$ \\
\hline PC & \multirow{3}{*}{ Nootropil Capsules ${ }^{\circledR}$} & 15.00 & 12.00 & $98.5 \pm 0.9$ \\
\hline & & 15.00 & 14.00 & $98.3 \pm 0.9$ \\
\hline & & 15.00 & 20.00 & $100.0 \pm 1.0$ \\
\hline & \multirow{3}{*}{ Nootropil tablets ${ }^{\circledR}$} & 15.00 & 12.00 & $99.7 \pm 0.7$ \\
\hline & & 15.00 & 14.00 & $99.5 \pm 0.7$ \\
\hline & & 15.00 & 20.00 & $100.4 \pm 0.7$ \\
\hline \multirow{3}{*}{ LV } & \multirow{3}{*}{ Tiratam tablets ${ }^{\circledR}$} & 10.00 & 6.00 & $99.7 \pm 0.3$ \\
\hline & & 10.00 & 10.00 & $100.3 \pm 0.3$ \\
\hline & & 10.00 & 12.00 & $100.2 \pm 0.3$ \\
\hline
\end{tabular}

a Mean $\pm \mathrm{SD}, n=3$.

\section{Analysis of pharmaceutical products}

The optimized procedure was successfully applied to the determination of TP, PC and LV in pharmaceutical formulations (Table VI). The results obtained were statistically compared with published HPLC methods $(4,9,10)$ for each drug. The results obtained by the proposed method agreed well with those of the published HPLC methods. The results were also compared statistically, using Student's $t$-test for accuracy and a variance $F$-test for precision, with those of the published methods at $95 \%$ confidence level. The results showed that the calculated $t$ - and $F$-values did not exceed the tabulated values, inferring that the proposed method is as accurate and as precise as published HPLC methods. 
G. M. Hadad et al:: Optimized and validated flow-injection spectrophotometric analysis of topiramate, piracetam and levetiracetam in pharmaceutical formulations, Acta Pharm. 61 (2011) 377-389.

Table VI. Determination of TP, PC and LV in pharmaceutical preparations by the proposed and published methods

\begin{tabular}{|c|c|c|c|c|c|c|}
\hline \multirow[b]{2}{*}{ Drug } & \multirow[b]{2}{*}{$\begin{array}{c}\text { Pharmaceutical } \\
\text { preparation } \\
\text { brand name }\end{array}$} & \multirow[b]{2}{*}{$\begin{array}{l}\text { Drug taken } \\
\left(\mu \mathrm{g} \mathrm{mL}^{-1}\right)^{\mathrm{a}}\end{array}$} & \multicolumn{2}{|c|}{ Found $\left(\mu \mathrm{g} \mathrm{mL} L^{-1}\right)$} & \multirow[b]{2}{*}{$\begin{array}{l}\text { Student's } \\
t \text {-value }\end{array}$} & \multirow[b]{2}{*}{$\begin{array}{l}\text { Variance } \\
\text { ratio } \\
F \text {-value }\end{array}$} \\
\hline & & & $\begin{array}{c}\text { Published } \\
\text { methods } \\
(4,9,10)^{\mathrm{b}}\end{array}$ & $\begin{array}{l}\text { Proposed } \\
\text { method }^{b}\end{array}$ & & \\
\hline \multirow{4}{*}{$\mathrm{TP}$} & \multirow{2}{*}{ Topiramate tablets ${ }^{\circledR}$} & 5.00 & $4.99 \pm 0.03$ & $5.00 \pm 0.02$ & 0.73 & 2.25 \\
\hline & & 35.00 & $34.86 \pm 0.20$ & $34.97 \pm 0.11$ & 1.28 & 3.31 \\
\hline & \multirow{2}{*}{ Delpiramate tablets ${ }^{\circledR}$} & 5.00 & $5.01 \pm 0.04$ & $4.94 \pm 0.04$ & 0.33 & 1.00 \\
\hline & & 35.00 & $34.90 \pm 0.29$ & $34.97 \pm 0.26$ & 0.48 & 1.24 \\
\hline \multirow{6}{*}{ PC } & \multirow{2}{*}{ Stimulan capsules ${ }^{\circledR}$} & 5.00 & $4.99 \pm 0.03$ & $4.98 \pm 0.04$ & 0.53 & 1.78 \\
\hline & & 35.00 & $34.72 \pm 0.23$ & $34.79 \pm 0.25$ & 0.55 & 1.18 \\
\hline & \multirow{2}{*}{ Stimulan tablets ${ }^{\circledR}$} & 5.00 & $5.01 \pm 0.04$ & $4.98 \pm 0.06$ & 1.10 & 2.25 \\
\hline & & 35.00 & $34.62 \pm 0.27$ & $34.83 \pm 0.41$ & 1.13 & 2.31 \\
\hline & \multirow{2}{*}{ Nootropil capsules ${ }^{\circledR}$} & 5.00 & $5.01 \pm 0.04$ & $4.98 \pm 0.04$ & 1.40 & 1.00 \\
\hline & & 35.00 & $34.90 \pm 0.28$ & $35.18 \pm 0.30$ & 1.81 & 1.15 \\
\hline \multirow{4}{*}{ LV } & \multirow{2}{*}{ Nootropil tablets ${ }^{\circledR}$} & 5.00 & $4.96 \pm 0.03$ & $4.95 \pm 0.02$ & 0.73 & 2.25 \\
\hline & & 35.00 & $35.07 \pm 0.18$ & $34.97 \pm 0.16$ & 1.10 & 1.27 \\
\hline & \multirow{2}{*}{ Tiratam tablets ${ }^{\circledR}$} & 5.00 & $4.98 \pm 0.04$ & $4.95 \pm 0.02$ & 1.77 & 4.00 \\
\hline & & 35.00 & $35.18 \pm 0.30$ & $34.97 \pm 0.16$ & 1.63 & 3.52 \\
\hline
\end{tabular}

a Based on label claim.

b Mean \pm SD, $n=7$.

c Tabulated $t$-value at the $95 \%$ confidence level is 2.18 ; tabulated $F$-value at the $95 \%$ confidence level is 4.18 .

The reported methods and the proposed method are compated in Table VII. The proposed method was found to be superior to the reported methods with respect to speed, simplicity, sensitivity and cost-effectiveness. It is less costly and it does not require expensive equipment or high-cost reagents like the reported HPLC methods (2, $6,8,9,11)$. 
G. M. Hadad et al.: Optimized and validated flow-injection spectrophotometric analysis of topiramate, piracetam and levetiracetam in pharmaceutical formulations, Acta Pharm. 61 (2011) 377-389.

Table VII. Comparison of analytical methods for TP, PC, and LV assays

\begin{tabular}{|c|c|c|c|c|c|c|}
\hline Drug & Method & Sample type & $\begin{array}{c}\text { LOD } \\
\left(\mu \mathrm{g} \mathrm{mL} \mathrm{mL}^{-1}\right)\end{array}$ & $\begin{array}{c}\text { LOQ } \\
\left(\mu \mathrm{g} \mathrm{mL}^{-1}\right)\end{array}$ & $\begin{array}{l}\text { Linearity } \\
\text { range } \\
\left(\mu \mathrm{g} \mathrm{mL}^{-1}\right)\end{array}$ & Ref. \\
\hline \multirow{4}{*}{ TP } & HPLC & Raw material & 5 & 1 & NA & 2 \\
\hline & HPLC & Oral solution & $\begin{array}{c}0.05 \% \\
(\mathrm{~S} / \mathrm{N}=3)\end{array}$ & $\begin{array}{c}0.1 \% \\
(\mathrm{~S} / \mathrm{N}=10)\end{array}$ & $16-2360$ & 3 \\
\hline & HPLC & Human serum & 0.005 & 0.04 & $0.04-40$ & 4 \\
\hline & FIA & $\begin{array}{l}\text { Pharmaceutical } \\
\text { formulation }\end{array}$ & 0.02 & 0.07 & $5-35$ & $\begin{array}{l}\text { This } \\
\text { method }\end{array}$ \\
\hline \multirow{9}{*}{ PC } & HPLC & $\begin{array}{l}\text { Piracetam and its } \\
\text { Four Impurities }\end{array}$ & $1.42 \times 10^{-3}$ & $0.42 \times 10^{-3}$ & $0.05-10$ & 5 \\
\hline & HPLC & Piracetam tablet & 18.9 & 56.7 & 100-1000 & 6 \\
\hline & $\begin{array}{l}\text { First-order } \\
\text { derivative spectra }\end{array}$ & $\begin{array}{l}\text { Bulk and phar- } \\
\text { maceutical for- } \\
\text { mulation }\end{array}$ & NA & NA & $10-80$ & 7 \\
\hline & $\begin{array}{l}\text { Ratio spectra } \\
\text { first derivative }\end{array}$ & $\begin{array}{l}\text { Pharmaceutical } \\
\text { formulation }\end{array}$ & 0.90 & 3.11 & $10-45$ & 8 \\
\hline & $\begin{array}{l}\text { Bivariate } \\
\text { calibration }\end{array}$ & $\begin{array}{l}\text { Pharmaceutical } \\
\text { formulation }\end{array}$ & 0.40 & 3.61 & $5-45$ & 8 \\
\hline & HPLC & $\begin{array}{l}\text { Pharmaceutical } \\
\text { formulation }\end{array}$ & 0.82 & 2.64 & $5-100$ & 8 \\
\hline & $\begin{array}{l}\text { Derivative ratio } \\
\text { spectrophotometry }\end{array}$ & $\begin{array}{l}\text { Pharmaceutical } \\
\text { formulation }\end{array}$ & 0.86 & 2.72 & $5-30$ & 9 \\
\hline & HPLC & $\begin{array}{l}\text { Pharmaceutical } \\
\text { formulation }\end{array}$ & 5 & 40 & $20-500$ & 9 \\
\hline & FIA & $\begin{array}{l}\text { Pharmaceutical } \\
\text { formulation }\end{array}$ & 0.04 & 0.11 & $5-35$ & $\begin{array}{l}\text { This } \\
\text { method }\end{array}$ \\
\hline \multirow{4}{*}{ LV } & HPLC & $\begin{array}{l}\text { LV and } \\
\text { degradants }\end{array}$ & NA & NA & $50-300$ & 10 \\
\hline & HPLC & LV enantiomers & 0.90 & 2.25 & $2.25-9.00$ & 11 \\
\hline & HPLC & $\begin{array}{l}\text { Pharmaceutical } \\
\text { formulation }\end{array}$ & NA & NA & $250-1750$ & 12 \\
\hline & FIA & $\begin{array}{l}\text { Pharmaceutical } \\
\text { formulation }\end{array}$ & 0.04 & 0.13 & $5-35$ & $\begin{array}{l}\text { This } \\
\text { method }\end{array}$ \\
\hline
\end{tabular}

NA - not available 
G. M. Hadad et al.: Optimized and validated flow-injection spectrophotometric analysis of topiramate, piracetam and levetiracetam in pharmaceutical formulations, Acta Pharm. 61 (2011) 377-389.

\section{CONCLUSIONS}

Derivatization of TP, PC, and LV with the OPA-ME method proved to be a simple procedure with excellent sensitivity. The use of flow injection methodology to automate the reaction led to considerable savings in analysis time and reagent consumption with small volumes of samples to be injected. The spectrophotometric FIA method developed is rapid, precise, accurate and of low cost and could therefore be of high interest to quality control laboratories or in the pharmaceutical industry for routine quantitative analysis of drugs.

\section{REFERENCES}

1. Martindale: The Complete Drug Reference (Ed. S. C. Sweetman), 36th ed., Pharmaceutical Press, The Royal Pharmaceutical Society, London 2009.

2. A. Biro, E. Pergel, G. Arvai, I. Ilisz, G. Szepesi, A. Peter and F. Lukacs, High-performance liquid chromatographic study of topiramate and its impurities, Chromatographia 63 (2006) S137-S141; DOI: 10.1365/s10337-006-0818-6.

3. M. Styslo-Zalasik and W.Y. Li., Determination of topiramate and its degradation product in liquid oral solutions by high performance liquid chromatography with a chemiluminescent nitrogen detector, J. Pharm. Biomed. Anal. 37 (2005) 529-534; DOI: 10.1016/j.jpba.2004.11.010.

4. G. Bahrami, S. Mirzaeei, B. Mohammadi and A. Kiani, High performance liquid chromatographic determination of topiramate in human serum using UV detection, J. Chromatogr. B: Anal. Technol. Biomed. Life Sci. 822 (2005) 322-325; DOI: 10.1016/j.jchromb.2005.05.032.

5. M. S. Arayne, N. Sultana, F. A. Siddiqui, A. Z. Mirza, F. Qureshi and M. H. Zuberi, Simultaneous determination of piracetam and its four impurities by RP-HPLC with UV Detection, $J$. Chromatogr. Sci. 48 (2010) 589-594.

6. A. D. Lestari, A. T. Prasetyo, T. Palupi, E. Umayah, M. Yuwono and G. Indrayanto, HPLC Determination of piracetam in tablets; Validation of the method, J. Liq. Chromatogr. Relat. Technol. 28 (2005) 1407-1416; DOI: 10.1081/JLC-200054893.

7. A. B. Anindita, K. R. Khandelwal, V. M. Deepali and K. Swapnil, Analytical method development and validation for piracetam as bulk and in pharmaceutical formulation, Int. J. Pharm. Tech. Res. 2 (2010) 201-204.

8. Y. S. I. El-Saharty, Simultaneous determination of piracetam and vincamine by spectrophotometric and high-performance liquid chromatographic methods, J. AOAC Int. 91 (2008) 311-321.

9. F. H. Metwally, B. A. Elzeany and H. W. Darwish, New methods for determination of cinnarizine in mixture with piracetam by spectrodensitometry, spectrophotometry, and liquid chromatography, J. AOAC Int. 88 (2005) 1666-1676.

10. G. Saravanan, G. Jyothi, Y. Suresh, A. Annerao, M. Ramakrishna, M. Yogeshwar Reddy and B. Ravibabu, LC method for the determination of the stability of levetiracetam drug substance under stressing conditions, Chromatographia 67 (2008) 173-177; DOI: 10.1365/s10337-007-0472-7.

11. B. M. Rao, R. Ravi, B. S. S. Reddy, S. Sivakumar, I. G. Chand, K. P. Kumar, P. V. R. Acharyulu, G. O. Reddy and M. K. Srinivasu, A validated chiral LC method for the enantioselective analysis of levetiracetam and its enantiomer R- $\alpha$-ethyl-2-oxo-pyrrolidine acetamide on amylose-based stationary phase, J. Pharm. Biomed. Anal. 35 (2004) 1017-1026; DOI: 10.1016/j.jpba.2004.03.015. 
G. M. Hadad et al.: Optimized and validated flow-injection spectrophotometric analysis of topiramate, piracetam and levetiracetam in pharmaceutical formulations, Acta Pharm. 61 (2011) 377-389.

12. S. Poongothai, V. Balaji, B. Madhavi, A. Rajasekhar Reddy, R. Ilavarasan and C. M. Karrunakaran, A sensitive dissolution test method for the development and validation of levetiracetam tablets by reverse phase-HPLC technique, Int. J. Pharm. Tech. Res. 3 (2011) 1023-1032.

13. K. Imai, T. Toyo'oka and H. Miyano, Fluorigenic reagents for primary and secondary amines and thiols in high-performance liquid chromatography, A review, Analyst 109 (1984) 1365-1373; DOI: 10.1039 /an9840901365.

14. International Conference on Harmonisation of Technical Requirements for Registration of Pharmaceuticals for Human Use, ICH Harmonised Tripartite Guideline - Validation of Analytical Procedures: Text and Methodology Q2(R1), Current Step 4 version, London 2005.

15. K. Zaitsu, M. Kai and K. Hamase, Reagent for UV-Vis Detection, in Modern Derivatization Methods for Separation Science (Ed. T. Toyo'oka), Wiley, New York 1999, p. 70.

\section{Optimirana i validirana protočna injekcijska spektrofotometrijska analiza topiramata, piracetama i levetiracetama u farmaceutskim pripravcima}

GHADA M. HADAD, RANDA A. ABDEL-SALAM i SAMY EMARA

Opisana je osjetljiva i brza protočna injekcijska analiza (FIA) za određivanje topiramata, piracetama i levetiracetama $u$ farmaceutskim pripravcima. Metoda se temelji na reakciji ortho-ftalaldehida i 2-merkaptoetanola u bazičnom puferu i mjerenju apsorbancije na $295 \mathrm{~nm}$ u protočnim uvjetima. U svrhu povećanja osjetljivosti i dobivanja reproducibilnih rezultata optimirane su varijable koje utječu na određivanje kao što su volumen injektiranog uzorka, $\mathrm{pH}$, ionska jakost, koncentracija reagensa, brzina protoka reagensa i drugi FIA parametri koristeći četvrt-frakcijski faktorijalni dizajn, za pet faktora na dva nivoa. Metoda je optimirana i potpuno validirana (linearnost, područje određivanja, granica detekcije i kvantifikacije, preciznost, selektivnost i točnost). Metoda je uspješno primijenjena za analizu farmaceutskih pripravaka.

Ključne riječi: topiramat, piracetam, levetiracetam, protočna injekcijska analiza

Pharmaceutical Analytical Chemistry Department, Faculty of Pharmacy, University of Suez Canal Ismailia 41522, Egypt

Pharmaceutical Analytical Chemistry Department, Faculty of Pharmacy, Misr International University Egypt 